\title{
The diversified teaching reform of The mixed flipped classroom Python Foundationcourse is aimed at deep learning
}

\author{
Xiaoxu Xiao ${ }^{1}$ \\ ${ }^{1}$ Guangzhou International Economics College, Guangzhou,510520, China
}

\begin{abstract}
Under the background of deep learning, the reform of diversified teaching mode is related to the community of teachers and students, and the traditional one-way independent learning of students is transformed into interactive independent learning of teachers and students. Through the MOOC, SPOC, such as teaching case analysis, to explore how to build a hybrid flip classroom teaching mode, use of the advantages of various platforms together, fully applied to the classroom teaching, the reasonable using and sharing high quality teaching resources, to ensure the ability of the students' learning and literacy, conducive to the students' active learning and teacher's guidance and the guidance of thinking, to increase the interaction between students and teachers, the construction of teachers and students "learning community" hybrid flip diversified teaching mode. This mode is applied in the teaching of Python Foundation course to promote the teaching reform of the course, help teachers improve the teaching quality, and provide reference for solving the problems faced by classroom teaching in colleges and universities as well as the teaching research of "MOOC+SPOC+ Flipped classroom" teaching mode.
\end{abstract}

\section{Introduction}

Deep learning refers to the process of deepening students' understanding in learning quality, that is, deep learning includes active and high-level understanding. Beattie et al. emphasized that deep learning emphasizes the establishment of a logical relationship between previous knowledge and experience and learning content, and the ability to critically understand the learning content [4]. The National Research Council Panel (hereinafter referred to as NRC) believes that deep learning is the process of student knowledge transfer and the improvement it brings to students' cognitive field, interpersonal field and personal field, including the mastery of core subject knowledge, critical thinking and complex problem solving. The interpersonal areas include teamwork and effective communication; Individual areas include learning to study and learning perseverance [5].

Flip class has changed the traditional teaching mode, the online and offline teaching organic combination, changed the students' learning space and time, through hybrid flip the classroom teaching, can the students' initiative and self-study combining, improve the enthusiasm of learning, so hybrid flip class in the modern teaching has very important significance.

The Python Foundation course in higher vocational colleges plays a very important role in the basic course of computer science. Through to turn the traditional teaching mode and teaching mode, give full play to the advantages of online and offline teaching learners through the study of mobile equipment, computer and so on carries on the platform, through the teacher set the question to carry on the guidance of fundamental study, and then to carry on the discussion between students and teachers, let can more deeply grasp knowledge, improve the students interest, initiative and creative, achieve the teaching effect.

\section{The feasibility of diversified teaching reform of the mixed flipped classroom Python Foundation course}

\subsection{Python FoundationCurrent situation of Course teaching}

In the field of computer science, the current professional education attaches great importance to the teaching of Basic Python course. First of all, almost all colleges and universities offer basic courses for Basic Python courses, but they start as soon as they start, without continuous bridging courses. Secondly, there is no unified teaching material for The Course Python Foundation. Many textbooks only explain the language without achieving specific teaching objectives, and students can only learn the language knowledge after learning. They have not yet had a deep understanding of artificial intelligence programming. Thirdly, the teaching force is limited, because artificial intelligence is a newly added major, many teachers are self-taught, there is no unified plan for Python course, teaching method is single. Finally, although relative to society, already more and more widely applied artificial intelligence, life is everywhere, but the cultivation of reserve talented person also

" Corresponding author: XiaoXuXiao@gziec.edu.cn, 23463537@qq.com 
restricted the development of colleges and universities is to implement the training talents, according to the present need of social development, to "professional, practice and knowledge of the senior talents demand is higher and higher, the demand of society has been pressing of" Python foundation "course teaching method reform.

\subsubsection{The advantages and disadvantages of mixed flipped classroom teaching mode used in Python Foundation}

Flip over traditional classroom carried on the thorough reform of classroom teaching, through the Internet + education mode, the teaching object of time and space changes, characters are flip, also said the learners from the traditional "teach me" flip "learning before teaching", by "focusing on the teacher's teaching" flip "to the learners' learning as the center". Through the change of teaching process, the real purpose of flipped classroom can be achieved.

By comparing the traditional teaching mode, the advantages of flipped classroom teaching can be highlighted. First of all, learners can have more personalized learning through flipped classroom, and can flexibly use time and space. Spatiality enables learners to conduct Internet + learning through mobile devices, and temporality enables learners to conduct content learning anytime and anywhere according to their own learning plans. Combined with the two, learners can learn repeatedly, and the online question-answering between teachers and students and the discussion between students and students can achieve more learning effects. Secondly, flipped classroom emphasizes that students are the subject of students and teachers become the object. In traditional teaching, teachers give lectures and learners accept passively. Through flipped classroom, learners learn independently through online teaching materials assigned by teachers, such as videos, PPT, homework, problem discussion and other documents. Learners can analyze the key and difficult points of knowledge through learning, and complete in-depth knowledge learning through homework, teacher-student discussion and student discussion. Finally, in class, by dividing learning into different study groups, teachers set different problems for discussion and research, and group members discuss and analyze problems to achieve learning objectives. The students' ability and initiative have been improved, and the teamwork spirit has also been cultivated and practiced[6].

\section{Construction of diversified teaching of Python Foundation in blended Flipped classroom of deep learning}

The traditional teaching mode still stays in the teacheroriented, the student is auxiliary, the student listens, the teacher speaks. Although traditional, but existence is necessary. Through the traditional face-to-face teaching, students can quickly acquire the basic knowledge points, but their initiative and thinking can not be mobilized. So turn the classroom teaching mode change this phenomenon, the students through online teaching resources, through the interaction between teachers and students, live interactive mode, more can mobilize students' thinking, from passive to active, through offline teaching, group teaching, each class set, let each student into roles are discussed, the problems of online teaching supplement, students can start thinking more, to achieve the teaching purpose. The Classroom of Python Foundation carries out flipped classroom teaching mode through the combination of online and offline teaching mode, emphasizes the subject learning status of students and the leading role of teachers in teaching, and makes the teaching methods diversified, teaching forms diversified and the teaching effect optimized.

There are three basic steps in the teaching process: pre-class preparation stage, classroom development stage and evaluation and reflection stage. How to set up these three links is a unified whole. If any step goes wrong, it will affect the effect of the teaching process.As shown in Figure 1 below: 


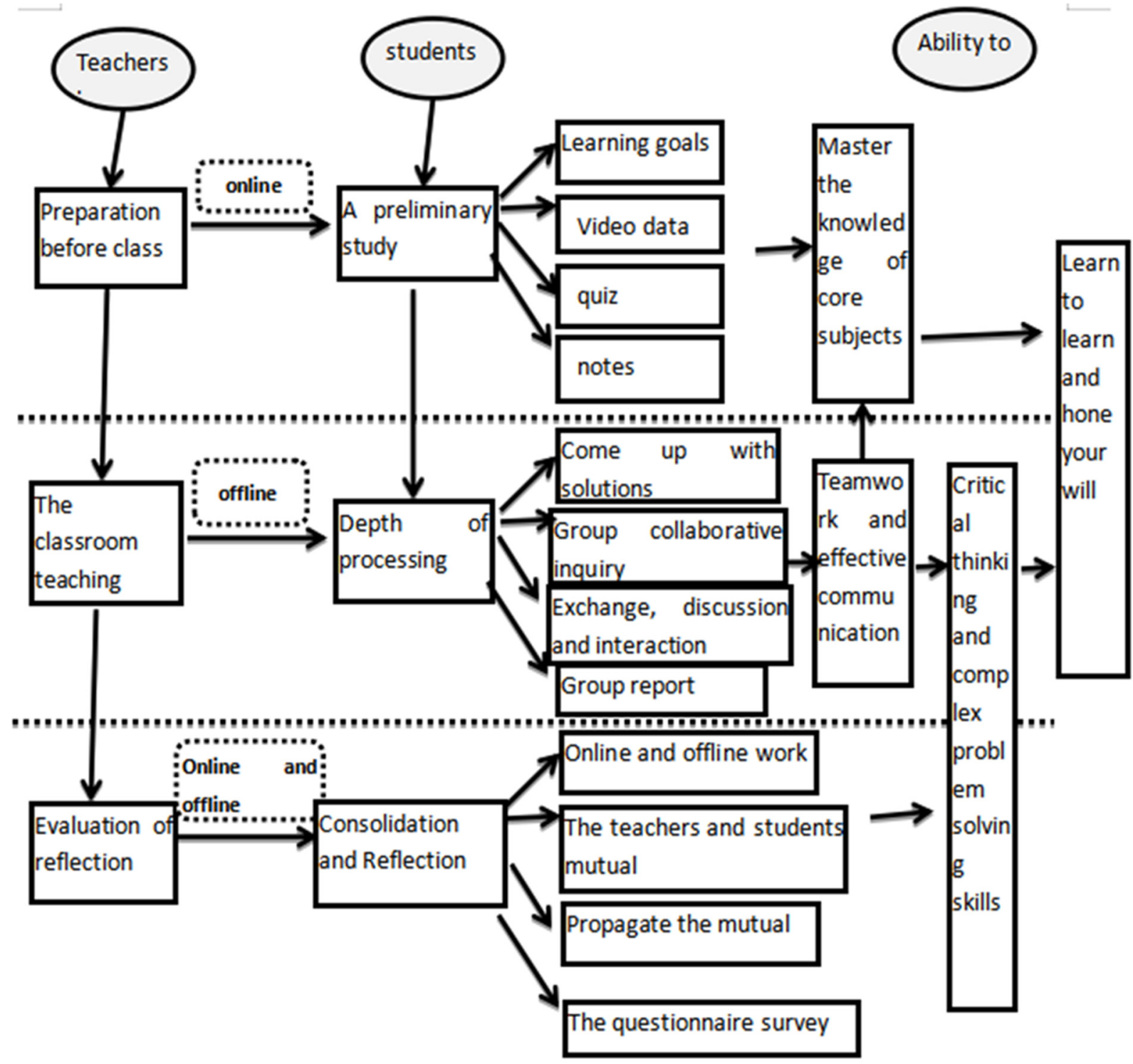

Fig1. A blended teaching model that points to deep learning.

\subsection{The preparatory stage before class}

Before class, first of all learners, learning objectives, learning content, learning environment and so on various aspects to carry on the analysis, through the analysis and design of teaching resources, select high-quality MOOC, and online, offline, and so on various aspects of teaching resources to carry on the design, and then through the resource platform course announcement, evaluation content, the content of the teaching unit, and upload short video, PPT, guiding document, such as teaching materials, in order to achieve better teaching effect, according to the students' learning level and the degree of knowledge ability, put students into the group leader of the study group, students use of online teaching resources free learning first, Then the problems set by teachers are discussed in groups to achieve the learning goals.

\subsection{Classroom development stage}

Students have mastered certain knowledge points through pre-class learning, but teachers' guidance in offline classroom teaching cannot be omitted. First of all, the classroom teaching design, the combination of online and offline teaching content of each class comprehensive arrangement, set rationality questions, according to the online content classification summary, can inspire students thinking. Secondly, the teaching content is designed. Teachers check students' pre-class learning through the resource platform before class to grasp students' learning problems, and focus on discussion and in-depth discussion on students' confused problems in class, so as to achieve the best teaching effect and avoid students' pre-class self-study only becoming a form. Finally, in classroom teaching, teachers teach through the process of intensive speaking, answering questions and summarizing in class, and students learn through the process of asking questions, discussing, reporting and summarizing in class. For example, through social cases, the course Python Foundation content design discussion, 
how to achieve artificial intelligence logistics through programming, so that students can grasp the knowledge, but also can stimulate students interest in Python language learning and initiative[7].

\subsection{Evaluation and reflection stage}

By combining online learning with offline learning, formative evaluation and summative evaluation, the teaching effect is evaluated from various aspects. Will be fully integrated into the class teaching evaluation of mutual activities, testing activities and competitions, using peer mutual (multiply mutual, mutual between groups), computer assisted assessment (test evaluation, teacher evaluation (reflection) evaluation of a variety of ways, from work or work, test, and reflect on multiple Angle of view to evaluate learners, more real and effective feedback on student's learning effect, so that teachers and students a targeted adjustment and improvement of teaching and learning activities.

After a period of study, seven related questions were set through the questionnaire star, mainly investigating the learner's recognition of the blended teaching mode of deep learning, learning effect and problems encountered. 98 copies were distributed and 95 copies were recovered, with the recovery and efficiency of $96.94 \%$ and $100 \%$ respectively.

\subsubsection{Recognition analysis}

In terms of the recognition degree of learners to the blended teaching mode of deep learning, the research finds that $85.26 \%$ of learners like this teaching mode. $86.32 \%$ believed that the teaching mode had a promoting effect on learning. Some learners hope to continue to adopt this teaching mode in the future, which is $84.21 \%$. Moreover, most students believe that the teaching mode can stimulate their interest in learning and develop their initiative and creativity in learning.

\subsubsection{Analysis of learning effect}

Referring to the framework of deep learning ability, the learning effect achieved by learners through the mixed teaching mode of deep learning is explored from the following three aspects: cognition field, interpersonal field and personal field. The results are shown in Table 1 below.

According to the above table 1, it can be seen from the cognitive field that learners who master the knowledge of core subjects reach $73.68 \%$, learners with critical thinking reach $91.58 \%$, and learners who solve complex problems effectively reach $85.26 \%$, indicating their recognition of this teaching mode.

Table 1. The study effect analysis of blended teaching mode in deep learning.

\begin{tabular}{|c|c|c|c|c|c|c|c|}
\hline $\begin{array}{l}\text { Field of deep } \\
\text { learning }\end{array}$ & $\begin{array}{l}\text { Deep learning } \\
\text { capability } \\
\text { framework }\end{array}$ & $\begin{array}{l}\text { Unhelpful } \\
\text { ( person) }\end{array}$ & $\begin{array}{l}\text { The } \\
\text { percentage }\end{array}$ & $\begin{array}{l}\text { Don't know } \\
\text { (people) }\end{array}$ & $\begin{array}{l}\text { The } \\
\text { percentage }\end{array}$ & $\begin{array}{l}\text { Helpful } \\
\text { ( person) }\end{array}$ & $\begin{array}{l}\text { The } \\
\text { percentage }\end{array}$ \\
\hline \multirow{3}{*}{$\begin{array}{l}\text { Cognitive } \\
\text { domain }\end{array}$} & $\begin{array}{l}\text { Master the } \\
\text { knowledge of } \\
\text { core subjects }\end{array}$ & 5 & $5.26 \%$ & 20 & $21.05 \%$ & 70 & $73.68 \%$ \\
\hline & Critical thinking & & $3.16 \%$ & 5 & $5.26 \%$ & 87 & $91.58 \%$ \\
\hline & $\begin{array}{l}\text { Complex } \\
\text { problem solving }\end{array}$ & 2 & $2.11 \%$ & 12 & $12.63 \%$ & 81 & $85.26 \%$ \\
\hline \multirow{2}{*}{$\begin{array}{l}\text { Interpersonal } \\
\text { field }\end{array}$} & $\begin{array}{l}\text { Team } \\
\text { collaboration }\end{array}$ & 3 & $3.16 \%$ & 15 & $15.79 \%$ & 77 & $81.05 \%$ \\
\hline & $\begin{array}{l}\text { Effective } \\
\text { communication }\end{array}$ & 2 & $2.11 \%$ & 12 & $12.63 \%$ & 81 & $85.26 \%$ \\
\hline \multirow{2}{*}{$\begin{array}{l}\text { Personal } \\
\text { domain }\end{array}$} & Learning to learn & & $3.16 \%$ & 10 & $10.53 \%$ & 82 & $86.32 \%$ \\
\hline & $\begin{array}{l}\text { Learning } \\
\text { perseverance }\end{array}$ & 2 & $2.11 \%$ & 13 & $13.68 \%$ & 80 & $84.21 \%$ \\
\hline
\end{tabular}

It can be seen from the interpersonal field that those who have teamwork ability reach $81.05 \%$ and can improve effective communication reach $85.26 \%$, indicating that the learning process is a process of teamwork, and the purpose of learning can be achieved through effective communication.

It can be seen from the personal field that learners' learning ability reaches $86.32 \%$ and their learning persistence reaches $84.21 \%$, indicating that learners can actively and actively improve their self-learning ability through learning in this teaching mode, learn deeply about teaching resources, set problems for teachers, and explore relevant resources to solve problems.

\section{The conclusion}

Educators have been thinking about a problem, now the Internet + era, how to guide students to play a greater role in mobile phones, return to the classroom[8]. Study in depth of basic course for the Python hybrid flip classroom mode, realize diversified teaching, through the teaching reform and practice show that the use of high quality 
online teaching resources, can improve the teaching of the teacher set the ability of organization, and students can enhance the students' initiative, from what has been discussed between teachers and students, live, have become more interesting landscape course, strengthen students' learning fun. Through the mixed and diversified teaching reform of Python Foundation course in higher vocational colleges, the classroom quality and teaching effect can be improved, and the teaching mode can be extended to other courses of computer, so as to achieve better training of computer talents.

\section{About the author:}

Xiao Xiaoxu (1980 ), Male, master, lecturer, research direction: artificial intelligence, network security.

\section{Acknowledgments}

2019 Featured Innovation Project of Education Department of Guangdong Province(2019GWTSCX087).

\section{References}

1. Han ,S.f, Wang, H. (2020) Online teaching mode and effective method to research the key links in implementing.wireless technology , 07:35-37.

2. Xie,Z.L, (2018)Research and Practice of online and Offline Integrated Teaching Mode Reform of"Internet + Classroom".Scientific Consulting (Science \&anagement), 5:51-52

3. Cheng X,Y, GengM,Die, (2020) An Exploration of blended online and Offline Golden course Construction based on MOOCS. Guangzhou Chemical Industry, 13:107-108

4. Zhang, X.J ,2019) An Analysis of Online and Offline Blended Teaching. Henan Education (Vocational Adult Education),10:135-136

5. Pang, J.W,(2017) Research on the Design of Evaluation Index of intelligent Classroom from the Perspective of Deep Learning. Modern Educational Technology,02:132-133

6. Zhu, Z.T,(2016) New Development of Intelligent Education: From Flipped Classroom to Intelligent Classroom and Intelligent Learning Space. Open Education Research,01:230-231

7. Wang,Y.Z,(2019) Research and Practice of Mixed Teaching Mode Based on Flipped Classroom -- A Case Study of Basic Chemistry in Higher Vocational Colleges. Science and Technology,11:189-190

8. Chen, S.J,(2020) Research on the Effectiveness of Personalized Tutoring after High school Mathematics in the Context of smart Classroom. Education Information Technology,04:230-231 